\title{
ICT and gamification experiences with CLIL methodology as inno- vative resources for the development of competencies in compul- sory secondary education
}

\author{
Elena Carrión Candel \\ elena.carrion@unir.net \\ Universidad Internacional de la Rioja (UNIR), Spain \\ Mercedes Pérez Agustín \\ mercedes.perez@unir.net \\ Universidad Internacional de la Rioja (UNIR), Spain \\ Elena Giménez De Ory \\ elena.gimenez@unir.net \\ Universidad Internacional de la Rioja (UNIR), Spain
}

\begin{abstract}
Due to the lack of research in the field of music through CLIL and ICT in Secondary Education in Spain, we propose to merge this subject with an innovative methodology. The general objective is to present a different approach to students in order to increase their motivation for the subject. The specific objectives are to teach music in English by integrating content, cognition and vocabulary through communication and the use of new technologies. This approach makes the design and implementation didactic, audiovisual and multimedia. Cuadernia: digital notebook composed of flash files, videos and audios, and gamification strategies. Quizziz: multiplayer questionnaire of class contents, based on teaching music through a cooperative methodology and gamification, are applied as options with a great educational projection, with information and innovative pedagogical experiences and potential to work together in the classroom with different levels of the subject. The results that follow the Likert scale reflect high student satisfaction with regard to teaching methodology, content acquisition, teacher training, ICT and resources. As a conclusion, of the coincident results between the professor and the students, we would like to implement it in the coming years.
\end{abstract}

\section{Keywords}

Music; multimedia resources; secondary education; digital games; CLIL methodology. 


\section{Introduction}

The new standard of teaching-approach proposed by Bologna addressed to a multicultural society focused on information and communication, with changes in family and social structures, creates a series of challenges in the educational context. Also, these advances mean a change in the rethinking of the orientation and methodology of the day to day life in educational institutions, since technology plays a part in our surrounding environment and daily life. Therefore, the training of the teaching staff is a key element for the inclusion and usage of the ICT in the educational process that allows to improve and facilitate the teaching-learning process, adapting to the necessities of each classroom and providing a suitable education for all students.

Thus new technologies and ICT applied to education have been reaching an increasingly significant role in the classroom and in the current teaching-learning processes, creating new roles for teachers in the societies and schools of the future, it has also changed the training scenarios and the way in which information is accessed, as well as other traditional elements of the teaching-learning processes, will also change the role of teachers in this situation. Currently, teachers' functions are more addressed to designing meaningful and motivating learning situations rather than transmitting readily accessible information. In this sense, many authors follow these approaches and consider ICT and audiovisual media as didactic tools that provide a new form to learning environments, and underline the implications that audiovisual media and communication technologies have on the new generations, conceived as "digital natives" (Ángel et al., 2011; Cabero Almenara \& Barroso Osuna, 2016; De Diezmas, 2018; Fernández Cruz \& Fernández Díaz, 2016; Fernandez Rodrigo, 2016; Rangel Baca, 2014), as young people today have grown up surrounded by technologies within a global and interconnected world, forming an essential part of their daily lives. We consider ICT an innovative and interesting resource to achieve the active, participative, autonomous and collaborative role of students inside and outside the classroom, at the same time as to encourage meaningful and experiential learning.

Moreover, with the high increase of bilingual schools in Spain there is also a high demand of CLIL (Content and Language Integrated Learning) methodology, which is based on the 4 C's principle (Content, Cognition, Communication and Culture). This is, to teach non-linguistic subjects like music, Arts or Physical Education through a foreign language. CLIL methodology clearly responds to this demand because it allows teachers to introduce the content of a language through a second language in a natural way. Some scholars point out the positive effect of CLIL programs as regards to language learning (Dalton-Puffer, 2007; Ruiz de Zarobe \& Lasagabaster, 2010) and others argue they have a negative effect on teaching specific contents like (Marsh et al., 2000). CLIL methodology seems to have a positive impact on students' learning because it works a wide range of educational areas (Vlachos, 2009) while other studies carried out by (Gallardo et al., 2009), highlight that pronunciation, syntax and accuracy are negatively affected.

Therefore, assuming all these approaches, the present proposal of educational innovation, comes from the need to develop a teaching-learning process based on the CLIL methodology that has its origin in the field of practice, motivating and interesting for students who contribute, complement and improve the learning of music.

We present this proposal to develop in the classroom, which uses ICT, gamification tools that bring a new approach to learning contexts, in our particular case, through the creation of new learning environments, in order to demonstrate that these methods are a positive stimulus for students, facilitate their learning and increase their degree of creativity, motivation, interest and participation, through an integrative educational model. 
We propose for its achievement a series of didactic and multimedia materials and gamification from a different perspective, in a parallel way to traditional teaching, since the implementation of strategies on Music through didactic resources, multimedia and application of ICT, provides the students significant and dynamic communication situations, fostering at the same time active, collaborative, dialogical and discovery learning, with the purpose of teaching in the knowledge, competences and abilities marked in the curriculum.

\section{Theoretical/ Conceptual Framework for the study}

\section{a. Music as a powerful tool to learn a foreign language}

A great number of studies prove that using music to teach a Foreign Language at different levels benefits the learning process from a linguistic, affective and sociolinguistic perspective. Language and music are similar due to their origin and progress. We can find the following similarities:

1. They are an innate capacity of human beings.

2. They are produced by the vocal-auditory system.

3. Music and language have fixed structures and codes that should be respected to be understood or felt. In the case of music through the notes and in language through grammar which universal, differs from one language to another.

4. Both means of expression allow human beings to be creative by combining the notes or the vocabulary or sentences, not adjusting too much to the fixed structures.

5. Both singing and speaking are developed at early stages in a spontaenous way, sometimes by imitation, focusing more on the sound that on the meaning or reaction it may cause.

6. As it happens with the acquisition of a mother tongue it is first processed by receiving input through listening and/ or reading and are then followed by productive skills.

On the contrary, some drawbacks can be found at the moment of fusing music and a foreign language. Due to the cultural attachment, sometimes songs cannot be translated because they are part of the way a group of people think or live and they have different phonemes so we cannot reproduce them using the same tones. The use of music in a foreign language classroom really helps to foster the 4 skills (reading, writing, listening and speaking) as (Jolly, 1975; Thain, 2010; Toscano-Fuentes, 2010) state and they influence positively in the incorporation of new grammatical elements and vocabulary (Falioni, 1993).

Music helps English language learners to express themselves in the foreign language in a more natural way. Moreover, music is a good way to explore the connections between language and cultural identity, as well as the different values and traditions in a globalised world. This can be achieved by playing songs, telling stories or rhymes typical of that country. A clear example of this is the use of Jolly phonics since pre-school to teach children all the English phonemes through songs and gestures. This methodology which combines Music (stressing the phonemes) and TPR (Total Physical Response) has been used in The UK since the 1960's and proves to teach children all the phonemes in 2 years. Jane Willis (2013) presented a series of activities where students are offered meaningful opportunities to learn music through English. As they were listening to the teacher they had to clap, use music signals or interact in English at the same time. As (Peregoy \& Boyle, 2008; Saricoban \& Metin, 2000) highlight, music helps English learners to develop the 4 skills furthermore boosts their motivation (Bartle, 1962; Jolly, 1975; Richards, 1969). 


\section{b. Why should we create digital materials specifically for Music through CLIL?}

One of the main difficulties CLIL teachers face is the lack of authentic and useful material to assess appropriate written and oral texts. The creation of this material requires teachers, who are experts on CLIL methodology, to know the content of the subject and master the foreign language, for this reason the bank of material is growing progressively. CLIL methodology will allow teachers to work in a more cooperative way fostering through the $4 C^{\prime}$ 's, critical thinking, autonomous learning and interaction. This methodology allows to introduce the new vocabulary through a more visual and auditive format that together with the ICTs creates a more appealing learning environment. ICTs contribute to transform the teaching-learning environment from a teacher-centered into a studentcentered approach. Students can create their own material and develop their creativity, problemsolving and cooperative learning. The use of ICTs in the classroom also presents some drawbacks as regards to teachers who lack digital competence. For the above considerations, ICTs present a perfect tool for CLIL methodology because we can work the 4 skills at the same time introducing the content, in a cooperative way from the students and teachers' perspective, following a constructivist approach. This will give into students having more confidence due to their proficiency on ICTs being at the center of the learning process.

Likewise, students daily live with new technologies and they find themselves totally familiarised with them, this is why teachers have to start from this reality to create in the actual context new situations of teaching-learning more ludic, attractive and enriching, reaching the perfect symbiosis between music and new technologies. It is a fact that ICTs therefore would contribute to teach Music through CLIL as follows:

- Developing active learning.

- Adding extra teaching material really useful for its authenticity.

- Working the High Thinking Skills, through videos they will be able to observe, do hypothesis, remember and analyze.

- Fostering cooperative learning because they will work in groups, take decissions and share different ways of thinking.

- Personalizing the subject since they can add their own information to the blogs or wikis and choose the topics they like best.

- Increasing meaningful learning.

Through Cuadernia and Quizzizes teachers can adapt the content to the language and learning approaches, because the use of "task" allows teachers to create an authentic environment and introduce pedagogic tools. Teachers can use further tools like Wikis, Cuadernia or other web sites to fuse traditional content of non-linguistic subjects like music, Arts or Physical Education in a more engaging and interactive way. Through CLIL and task-based learning, students learn how to work cooperatively using authentic and up to date material. Globalisation and development of new technologies provides us a new era known as the Knowledge Age. This has given into radical changes as regards to how societies work and the service given by educational systems (Coyle et al., 2010).

However, we must bear in mind that technology is not a synonym of meaningful learning, for ICTs to be really useful in an educational context they should be used when the students are developing their thinking capacity (Mehisto et al., 2008). In this sense, the use of ICT and especially this innovative gamification proposal, has added to education a new way of learning and participating, a new paradigm in the process of teaching learning. Many experts highlight the implications of audiovisual media and communication technology on young people and the necessity to include specific criteria to educate using gamification and new technologies (Burke, 2014; Espeso, 2017; Giráldez, 2010; Kaap, 2012; Roca, 2004; Romero-Carmona, 2004; Teixes, 2015) among others. Proposing 
to the educator the design, use, planning and elaboration of their own materials, innovating and adapting to the necessities and interest of the students to make it suitable for all the learning situations, exploring new teaching methods, strategies for evaluating the process and results.

\section{Material and Methods}

The research aims to know how the integration and application of ICTs and gamification occurs in the learning of secondary students in a specific subject of the curriculum, with the purpose of a possible extension to similar ones (Pantoja Vallejo \& Montes, 2010).

\section{a. Objectives}

The general objective of this educational proposal is to verify the effectiveness of the application of the cooperative learning methodology and gamification in the classroom, as well as to measure the degree of satisfaction generated among the students.

The specific objectives are to use technological tools on music to improve and innovate in the teaching-learning process, to learn to learn and know how to do; perform gamification activities in the classroom, as a means of acquiring and developing knowledge, skills and abilities for the learning of music in an active and meaningful way; develop critical analysis and judgment, as well as interest and motivation for the music subject.

\section{b. Contextual research}

The Diego de Siloé Institute in Albacete has had a bilingual line since the academic year 2017/2018, giving into a higher level of English in the different subjects. Therefore, all Secondary Education students in this center are part of the Bilingual Project including subjects such as: Geography and History, Biology and Geology, Physics and Chemistry, Mathematics and Music. The center has four conversation assistants annually who are chosen by the Ministry of Education to support oral skills for students and teachers, mainly focusing on speaking and listening.

The educational experience was developed in a public bilingual Secondary Education center, Diego de Siloé, located in Albacete (Castilla La Mancha) with a total study population of 338 students. This didactic project was implemented in the subject of music in English specifically in the 2nd and 3 rd years of Secondary Education within the center's Bilingual Project. Eleven male and female students ranging 14 and 16 years old participated in it and were distributed in five groups. The duration of the session was four class sessions ( 55 minutes per session). And for its development and implementation, the students worked especially in groups in a collaborative way and two key elements were used: the use of technologies and classroom gamification.

\section{Instruments}

To evaluate the student's participation and their perception and evaluation of the learning process, the constructs analyzed in this paper, we mainly use two instruments of analysis. First, the direct observation of the teacher, from the knowledge, participation and significant interventions of the students in the realization of ICT resources and gamification that worked in the classroom, and second, the students' answers in the online survey, through the Google Drive application. This survey, presented to 111 students of the Secondary Education Institute Diego de Siloé, located in Albacete, 
ICT and gamification experiences with CLIL methodology as innovative resources for the development of competencies in compulsory secondary education

consists of 15 elements that can be found in the following URL: Google Drive Application: https:// goo.gl/forms/0asgbK3NqTOmpfjI2

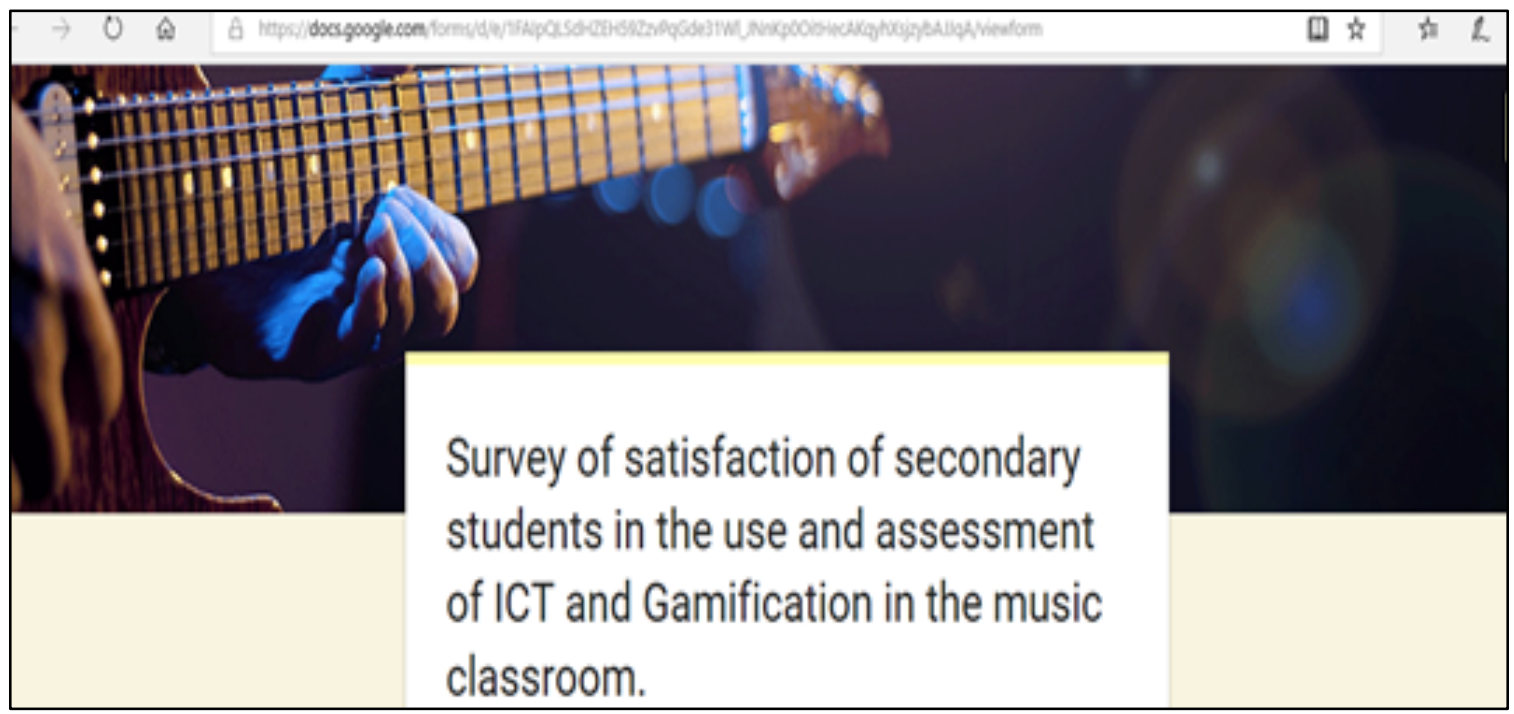

Figure 1. Survey of satisfaction of university students in the use and assessment of ICT and Gamification in the music classroom.

Also, to know the music teachers' opinion on the use of ICT and gamification in the subject, a survey with 15 items was used to evaluate the effectiveness of these materials and the appreciation of the possible changes registered in the students. We have evaluated, therefore, the results of our research of two areas, students and teachers. The survey answered by the music teacher can be found in the following URL:

Google Drive Application: https://goo.gl/forms/SgtPbM50doD1vloq1

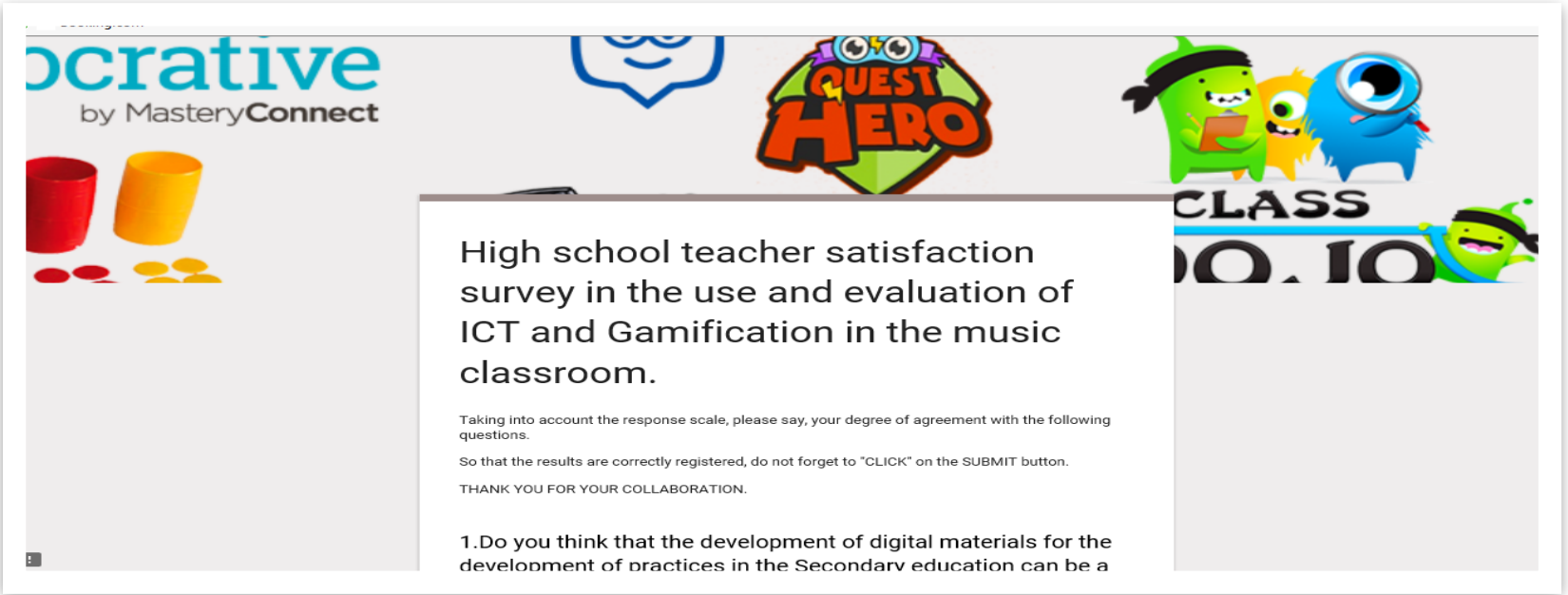

Figure 2. High School teacher satifaction survey in the use and evaluation of ICT and Gamification in the music classroom. 


\section{d. Design and procedure of the didactic proposal}

Digital resources for educational purposes grow exponentially in all areas of knowledge. There are numerous studies that indicate that the integration in the classroom of multimedia resources has provided a possibility of improvement to the educational process. In this section, two innovative didactic proposals that can be introduced in the classrooms - Cuadernia and Quizzizz-, with these resources together with the students' involvement is encouraged in the learning process, encouraging their motivation in the subject, through team work and obtaining individual achievements. The structure of this section has a didactic and practical nature, since its intention is directly focused on the contribution to teaching, through the development and implementation of new training strategies and development of interesting gamification and multimedia materials, and attractive for students, who support themselves in the use of new technologies with the aim of improving teaching praxis and interest in the subject of Music.

Next, we show the description and explanation of the multimedia and gamification of music produced resources - Cuadernia and Quizizz - for analysis and reflection by the students.

\section{Cuadernia: Interactive digital book: "The Instrument families"}

It is an easy to use tool that allows us to create eBooks in the form of workbooks full of multimedia and educational activities to learn through play in a visual way. In Cuadernia you can play videos and sounds and create activities to foster students' interaction. It is an innovative development made in Castilla-La Mancha with big expectations for the future as it has completed all of the National and European standards as a digital educational resource maker.

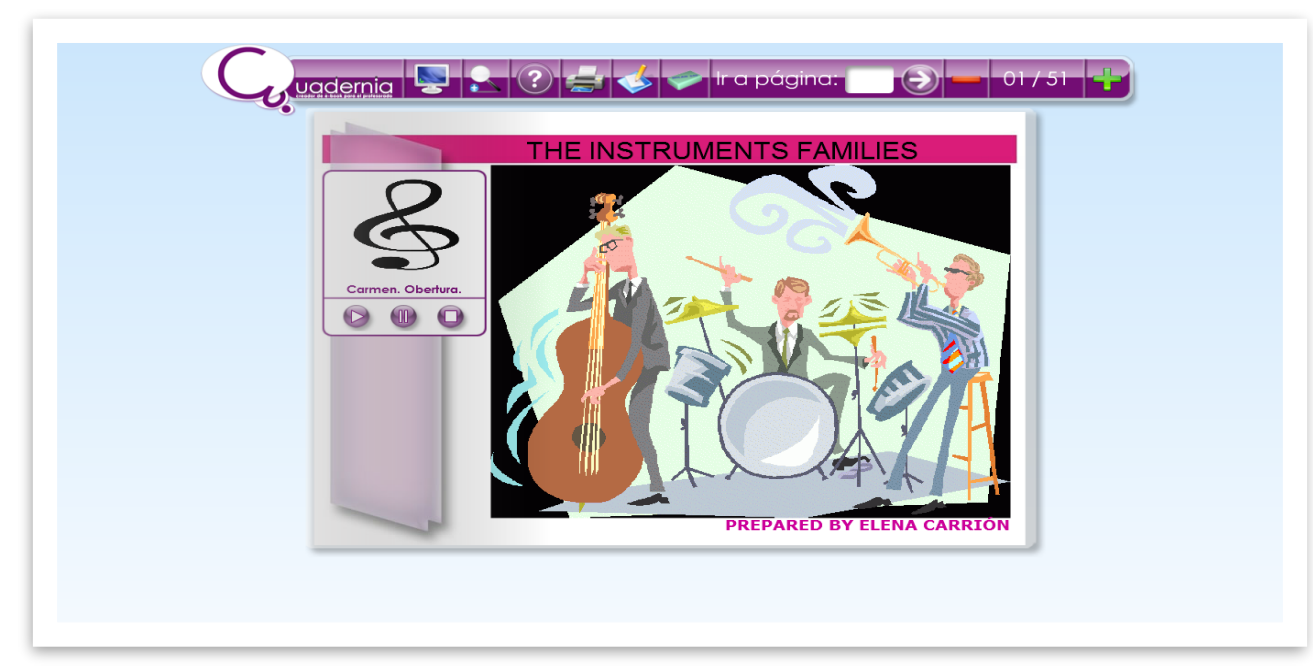

Figure 3. Cuadernia "The Instrument families"

In this activity we are going to use an e-book (a digital resource made in Cuadernia) to explain the different instruments in an orchestra and the instruments families such as: string family, brass family, woodwind family and the percussion family which include the pitched and unpitched instruments. In this Cuadernia we can find useful and didactic multimedia tools to teach the main characteristics of the instruments of the orchestra. Our students can also learn by doing different instruments, watching interesting videos of the orchestra or listening to the sound of the different instruments to be able to recognize them. So, this is an attractive and interactive resource for learning. First, the students will look at the presentation that has the form of an eBook but the appearance of a power point, from this the students will be able to identify all of the important information that they will later need to carry out the activities at the end. 
We will use this Cuadernia - digital book made by the teacher- to explain the different instruments of the orquestra and instruments families working on the following objectives:

- To identify the four families of instruments in an orchestra

- To learn the basic instruments of the orchestra vocabulary.

- To listen and recognize the instruments of the orchestra.

- To identify the different sounds each instrumental group makes.

- $\quad$ To be able to distinguish between the different types of musical instrument groups.

For this, we will consider the following methodological steps:

1. Viewing the Cuadernia: "The Instruments Families".

2. We will carry out with the group-class the explanation of the different instruments of the orchestra and the characteristics of the different instrumental families, through the viewing of different videos of the orchestra or the active listening to the sounds of the different instruments that make up the template orchestral, for later recognition and identification.

3. The students will carry out, through group work and small group dynamics, the various activities proposed in the Cuadernia and the various expansion and reinforcement games, such as: matching, filling the gaps, answering questions, doing an instrument word search, identifying different sounds with their corresponding image, etc. All this to verify if the student has assimilated and understood all the proposed contents, promoting meaningful, collaborative learning and the competence of learning to learn.

Among the ICT resources available to teachers to teach languages, we highlight this Cuadernia for its enormous educational potential to develop both writing and oral communication in a foreign language. Therefore, the digital tools developed contribute adequately, on the one hand, to the use of ICT resources for language teaching and learning and, on the other hand, they enable greater interactivity and meaningful learning through activities of discovery, analysis and reflection. Therefore, to respond to music education in the 21st century, a new and different approach to learning has been designed, which makes it possible to achieve it through a student's-centered methodology, as the protagonist and active part in the educational process, promoting motivation. and student interest in the subject of music in English, where learning has been considered in an active, constructive, and cooperative way, and the student learns as a result of interaction and work with others.

\section{Activity 1. Review Task}

The teacher divides the class into various groups to carry out the activities in a cooperative way and we are going to use computers to resolve all these tasks. (If necessary, the class has to move to a separate computer laboratory). In this Cuadernia we can find useful and didactic multimedia tools to teach the main characteristics of the instruments of the orchestra, also our students can learn by doing different exercises, so this is an attractive and interactive resource for learning. Below we show the activities included in the prepared digital book:

1. Match with arrows. Students have to join each instrument with the corresponding instrument family word. (It is an interesting resource to learn the vocabulary of the different instrument families) 


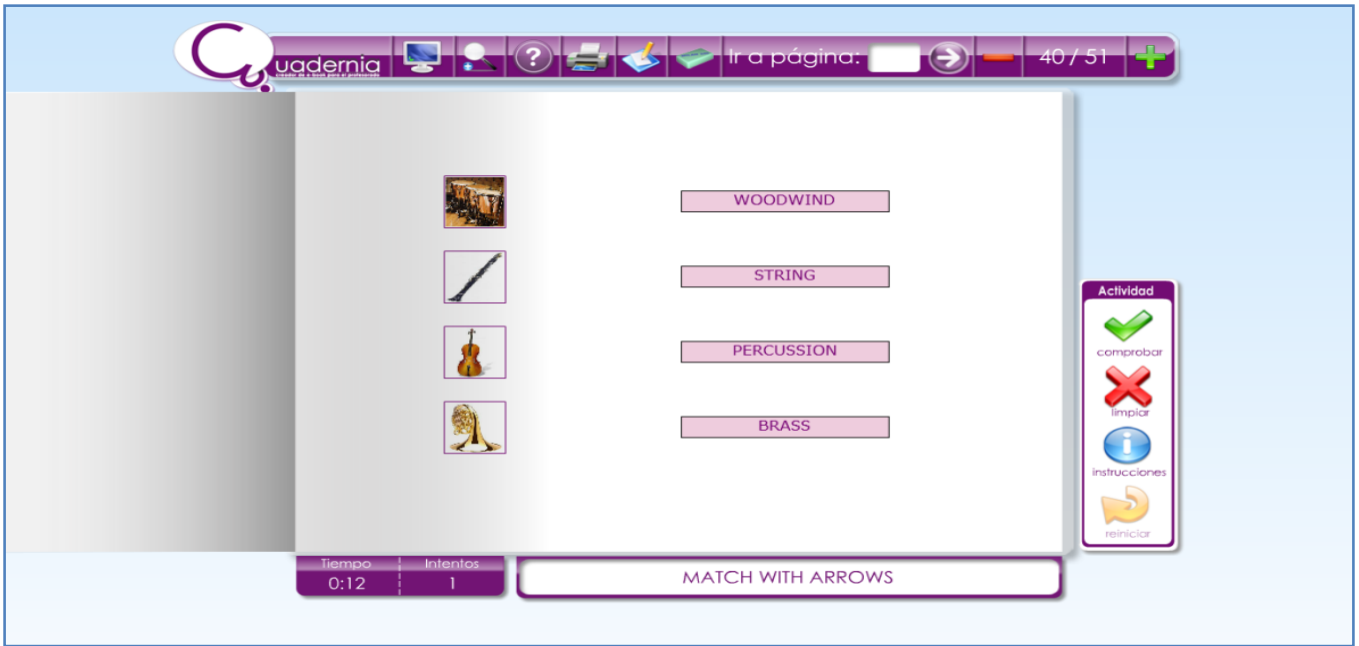

Figure 4. Match with arrows.

2. Find the instruments. Students have to find the following instruments in the word search, the first group to find all of the target words in the word search and circle them wins. (It is an interesting resource to learn the vocabulary of the different instruments).

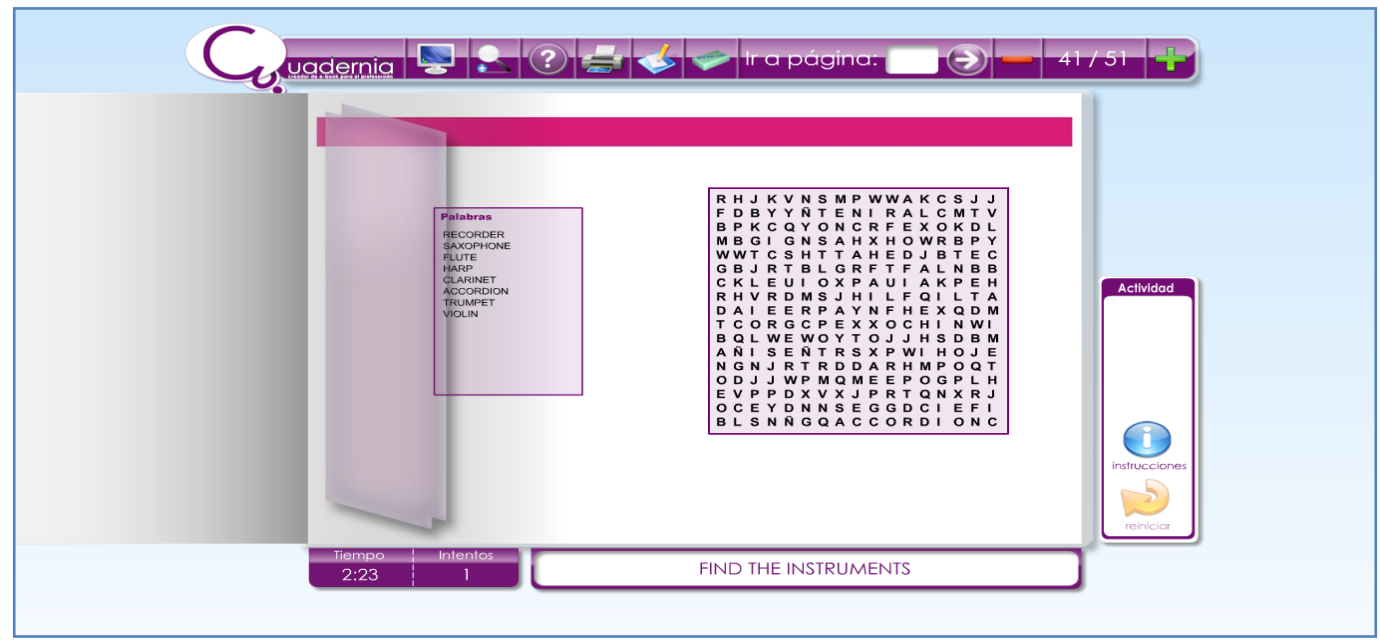

Figure 5. Find the instruments.

3. Answer the questions. In these activities we are going to check the understanding of the learned vocabulary about the instruments. They will have to answer questions with the multiple choice answers or explain diverse concepts or vocabulary from the unit. (It is an interesting resource to learn the vocabulary of the unit). 


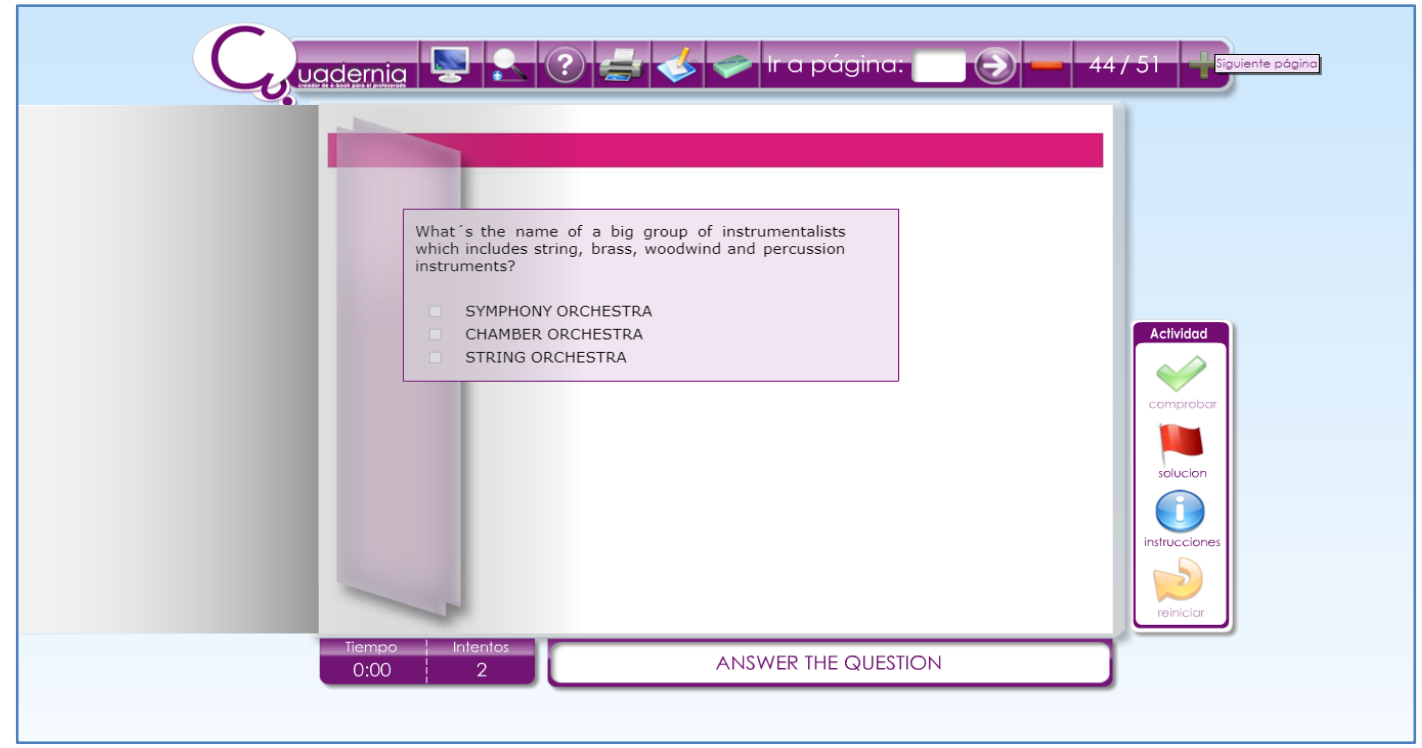

Figure 6. Answer the question

4. Answer the questions with images. In these activities we are going to check the understanding of the learned vocabulary about the percussion instruments. They will have to answer questions or explain diverse concepts or vocabulary from the unit. (It is an interesting resource to learn the vocabulary of the unit).

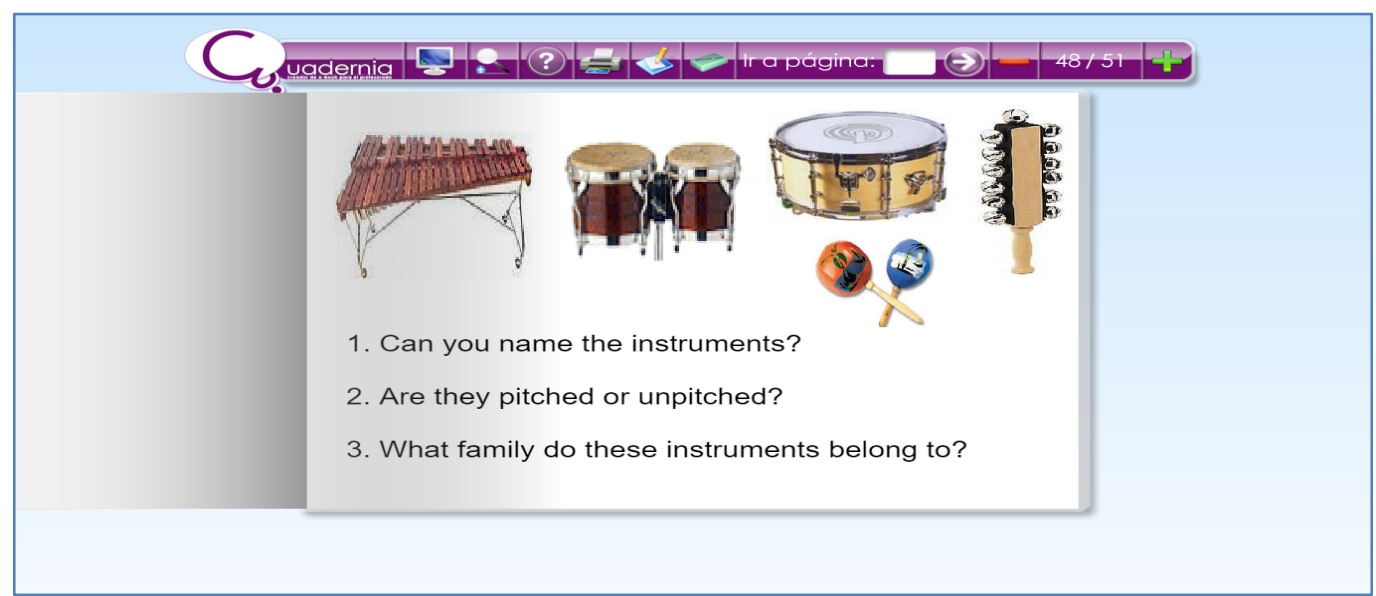

Figure 7. Answer the question with images.

As we have shown, with the elaboration of this interactive digital book the students will carry out through group work dynamics and in small groups, the different activities proposed and the different extension and reinforcement games, such as: activities to match with arrows, fill in the gaps, answer questions, do a word search for instruments, identify different sounds with their corresponding image, etc. All this to check if the students have assimilated and understood all the proposed contents, promoting meaningful, collaborative learning and the competence of learning to learn in the subject of Music.

\section{Quizziz: The Concert, the instruments of the orchestra}

Regarding to current methodologies which are available today, gamification with technologies can be very useful in the didactics and music learning because this technique clearly connects with the digital composition of the new generations of students, trying to awaken students' curiosity, their 
creativity and teamwork and cooperative learning. The two proposals presented in this article coincide in this line of action: "teach having fun, have fun teaching", terms that should not be far from the classroom dynamics, in short, let's make schools a place where young people feel like going.

Quizziz is a multiplayer question game similar to Kahoot. This tool allows the teacher to create a question and answer quiz for a ludic and game changing education. This digital tool is gaining followers to engage students in learning and even offers the option to evaluate them in a very simple way when collecting the data of the answers.

From the Quizziz, educational tool that rivals the Kahoot, we can highlight certain very interesting features:

- The statements of the questions are also seen on the mobile device.

- It allows us to send elaborate activities as homework.

- You can share activities with Google Classroom.

- Activities can be printed to be distributed in class.

- Assign avatars for each player which increases the feeling and motivation of the game.

- You can enter funny Memes that are displayed once a question is answered.

The teacher generates the questions and students enter a page that will indicate the Web to enter a code or PIN that gives them access to the questionnaire. They can access it from their mobile devices, tablets or computers and register with the desired alias and their name will appear on the screen.

The Quizziz URL is the following:

https://quizizz.com/admin/quiz/5b79c559965174001afbd285/the-concert-the-instruments-of-theorchestra

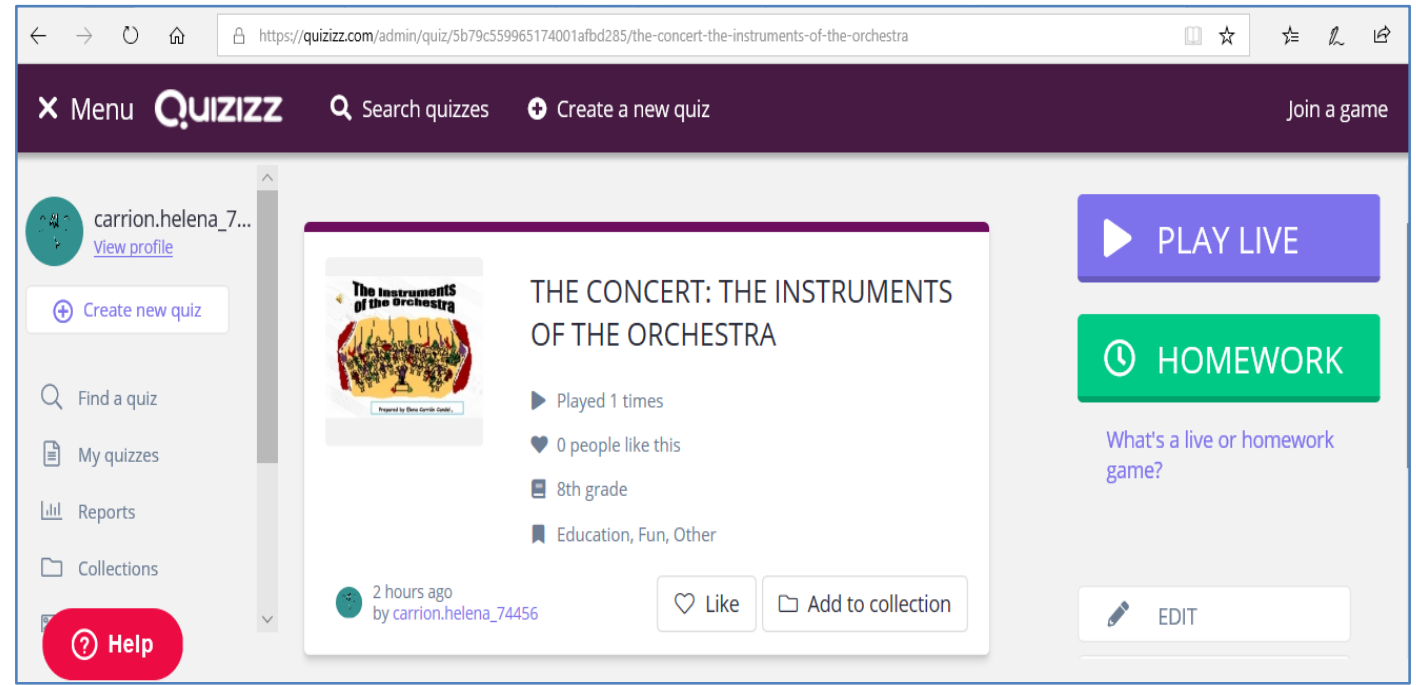

Figure 8. Quizziz: The Concert, the instruments of the orchestra.

Once in, the users answer the questions using the mobile as a control pad. On their screens there will appear four colours, each one showing a possible answer to the question (Figure 9). 


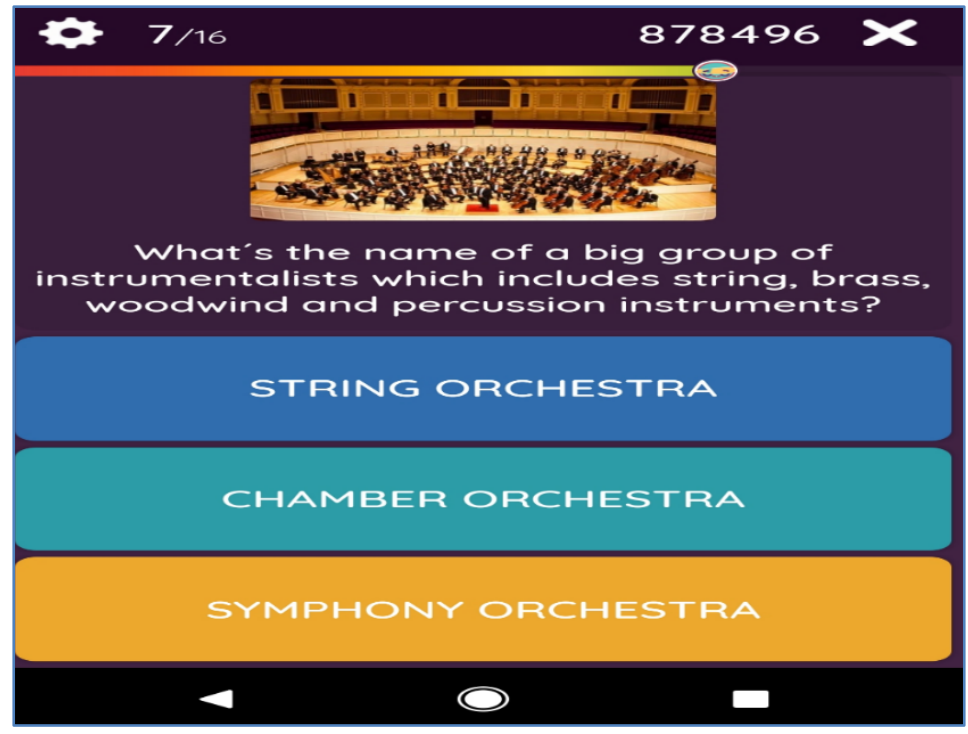

Figure 9. Sample question and response options

In our case it allows us to learn and review concepts and musical contents, specifically the different instrumental families and the instruments of the orchestra in a fun and entertaining way, simulating a contest. The idea is to learn by playing, that is to say, this Web service of social and gamified education, behaves like a game rewarding those who progress in the answers with a higher score that will place them at the top of the ranking.

Here are some examples of questions that appear in this Quizziz (Figure 10, 11):

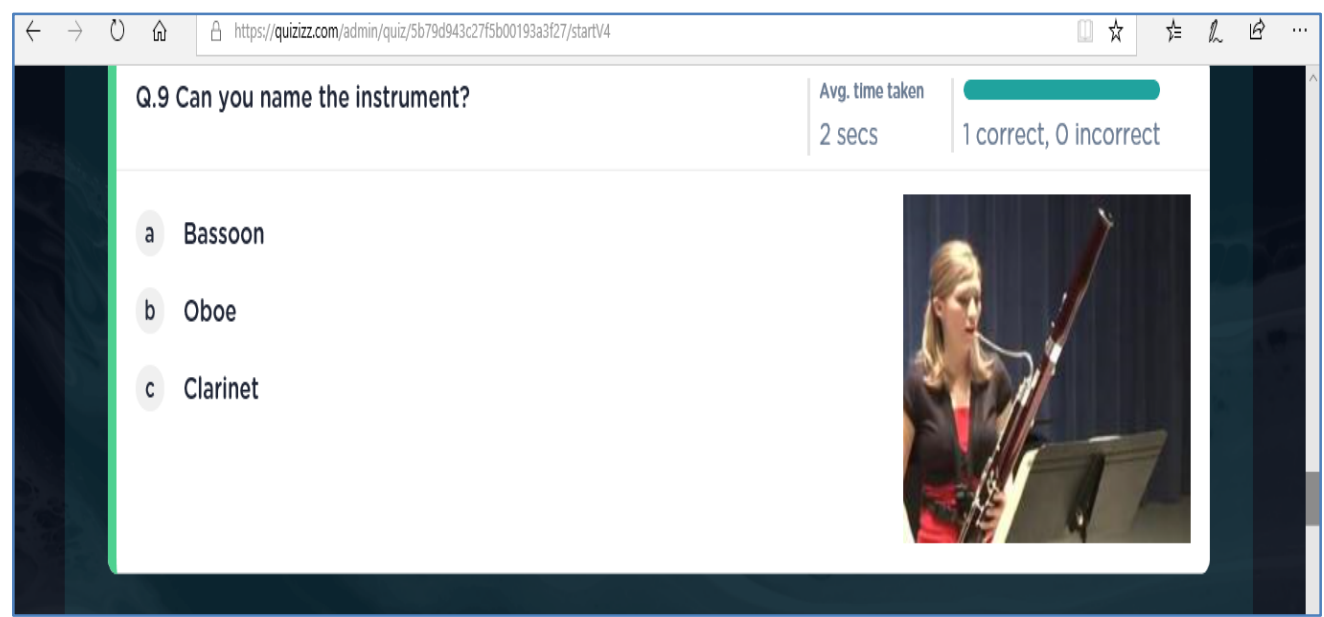

Figure 10. Quizziz: The Concert, the instruments of the orchestra. 


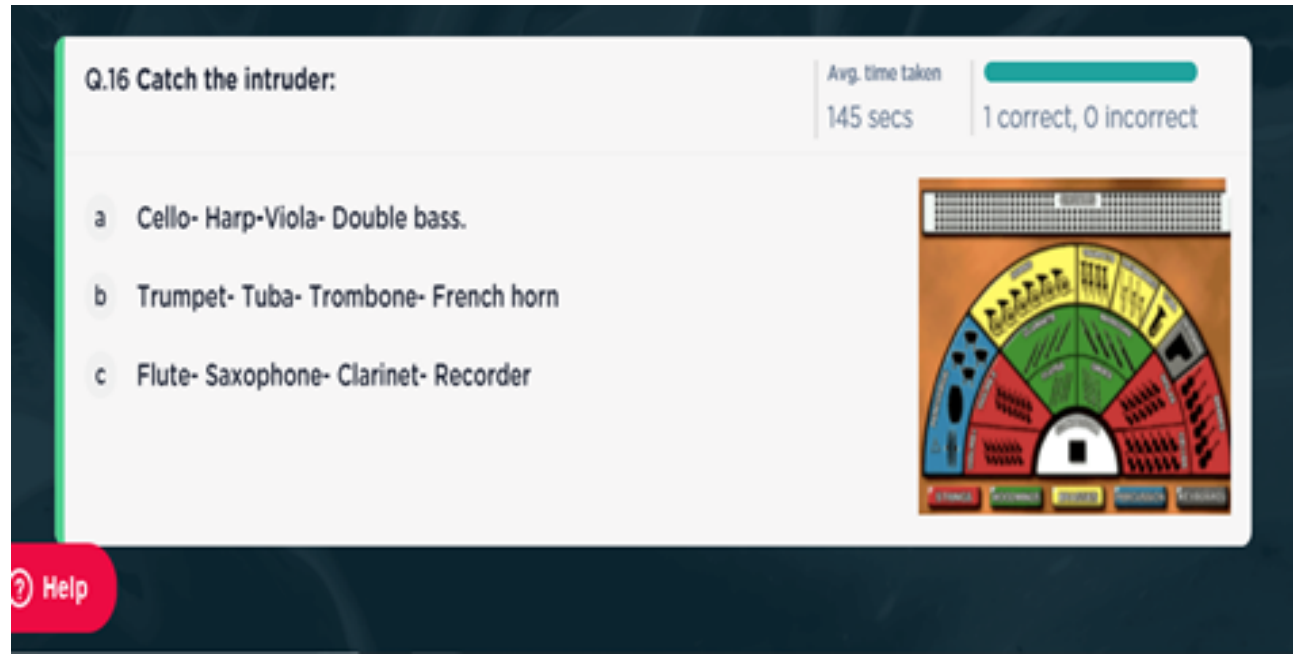

Figure 11. Quizziz: Catch the intruder

With the Cuadernia and the Quizizz prepared, we justify that the introduction of technology in the classroom has changed the way of teaching and offers us new possibilities, since we are currently facing a society in constant change and we cannot allow education to remain rigid and inexorable. Therefore, this educational proposal allows the construction of knowledge and the teaching of music in bilingual education through content and language learning (CLIL) in an attractive, meaningful and motivating way for students.

\section{Analysis and Results}

To verify the adequacy of the proposed method among teachers and students we have established the hereby categories: 'Teacher methodology', 'Content Acquisition', 'Teacher training' and 'ICTs'.

We will analyse the importance of each category individually.

Teacher methodology should be taken into consideration due to the various studies of digital skills among CLIL and non-CLIL students. In their 2014 report, Scott and Beadle (2014) acknowledged how effective digital technologies and CALL (computer assisted language learning) were in language learning, particularly for pronunciation (Saz et al., 2011), reading skills, motivation (Dourda et al., 2013) vocabulary retention (Baturay et al., 2009), and for focusing on form in writing tasks (Adams et al., 2015). Another line of research aims at disseminating particular experiences implementing ICT in CLIL settings for all education levels. For example, (Rodríguez et al., 2014) described the use of Hot Potatoes, Scratch and What2Learn in physics and chemistry, whereas (Fontecha, 2014) showed an example of a CLIL quest on climate change. In turn, (Vlachos, 2009) explained the implementation and results of webquests in the CLIL classroom, (Gaballo, 2010) reflected on the use of digital resources in bilingual subjects. The next line of research aims to teach music through CLIL, teaching a foreign language through music benefits to learn the target language (Bartle, 1962; Jolly, 1975; Peregoy \& Boyle, 2008; Richards, 1969; Saricoban \& Metin, 2000). In the same vein music helps learners develop their listening, speaking, reading and writing skills and due to its cross-curricular nature boosts students' motivation.

For this reason, we consider these variables allow us to globally evaluate the success of this methodology.

The results will be assessed through a questionnaire displayed in Table 1. The established categories will be evaluated by specific items: 
1. Teacher methodology. Questions:1, 5, 6, 8, 9 and 12 .

2. Content Acquisition: 2, 7 and 13.

3. Teacher training: 3.

4. ICTs: 4, 10 and 11 .

The scoring system is Likert-based ranging from 1-5.

\begin{tabular}{|c|c|}
\hline Items & Questions \\
\hline Question 1 & $\begin{array}{l}\text { Do you think that the development of digital materials for the development of prac- } \\
\text { tices in the Secondary education can be a valid instrument for learning Music? }\end{array}$ \\
\hline Question 2 & $\begin{array}{l}\text { Do you think that these didactic and multimedia and gamification resources have } \\
\text { contributed to improve your knowledge of the subject of Music? }\end{array}$ \\
\hline Question 3 & $\begin{array}{l}\text { Do you consider it necessary for future Primary and Child teachers to acquire know- } \\
\text { ledge or skills in new technologies? }\end{array}$ \\
\hline Question 4 & $\begin{array}{l}\text { Do you think the use of new technologies for the learning of any subject is adequa- } \\
\text { te? }\end{array}$ \\
\hline Question 5 & $\begin{array}{l}\text { Do you consider that new technologies and the use of gamification improve and } \\
\text { complement the traditional ways of teaching and learning? }\end{array}$ \\
\hline Question 6 & $\begin{array}{l}\text { Do you think this method of learning and teaching has improved your understan- } \\
\text { ding in Music subject? }\end{array}$ \\
\hline Question 7 & Do you think this method can improve the knowledge of music in future students? \\
\hline Question 8 & $\begin{array}{l}\text { Do you think that this method can improve teaching practice and contribute to qua- } \\
\text { lity music education? }\end{array}$ \\
\hline Question 9 & $\begin{array}{l}\text { Do you think that teaching nowadays requires the incorporation of new technologi- } \\
\text { es and gamification? }\end{array}$ \\
\hline $\begin{array}{l}\text { Question } \\
10\end{array}$ & $\begin{array}{l}\text { Do you think that the use of gamification and learning through the game improves } \\
\text { learning and motivation for the subject of Music? }\end{array}$ \\
\hline $\begin{array}{l}\text { Question } \\
11\end{array}$ & $\begin{array}{l}\text { Do you think that these forms of learning based on the use of ICT and gamification } \\
\text { favor dialogue and cooperative work in the music classroom? }\end{array}$ \\
\hline $\begin{array}{l}\text { Question } \\
12\end{array}$ & $\begin{array}{l}\text { Do you consider your work in the classroom positive and meaningful by using these } \\
\text { methods? }\end{array}$ \\
\hline $\begin{array}{l}\text { Question } \\
13\end{array}$ & $\begin{array}{l}\text { Do you think that this method has improved your comprehension in the subject of } \\
\text { English music? }\end{array}$ \\
\hline
\end{tabular}

Table 1. Satisfaction survey among students 


\begin{tabular}{|l|l|l|l|l|l|l|}
\hline Categories & Question & low & neutral & high & mean & sd \\
\hline \multirow{4}{*}{$\mathbf{1}$} & $\mathbf{1}$ & 0 & 0 & 100 & 4.426 & 0.497 \\
\cline { 2 - 7 } & $\mathbf{1 2}$ & 0 & 0 & 100 & 4.423 & 0.496 \\
\cline { 2 - 7 } & $\mathbf{5}$ & 0 & 1.802 & 98.198 & 4.441 & 0.534 \\
\cline { 2 - 7 } & $\mathbf{6}$ & 0 & 1.802 & 98.198 & 4.423 & 0.531 \\
\hline $\mathbf{9}$ & 0 & 2.679 & 97.321 & 4.3125 & 0.520 \\
\hline \multirow{3}{*}{$\mathbf{2}$} & $\mathbf{8}$ & 0.9001 & 1.802 & 97.297 & 4.405 & 0.578 \\
\hline \multirow{3}{*}{$\mathbf{3}$} & $\mathbf{1 3}$ & 0 & 0 & 100 & 4.509 & 0.502 \\
\hline \multirow{3}{*}{$\mathbf{4}$} & $\mathbf{7}$ & 0 & 0 & 100 & 4.491 & 0.502 \\
\hline & $\mathbf{3}$ & 0 & 2.703 & 97.297 & 4.279 & 0.508 \\
\hline & $\mathbf{4}$ & 0 & 0.893 & 99.107 & 4.446 & 0.517 \\
\cline { 2 - 7 } & $\mathbf{1 0}$ & 0 & 0 & 100 & 4.536 & 0.501 \\
\cline { 2 - 7 } & $\mathbf{1 1}$ & 0 & 1.786 & 98.214 & 4.375 & 0.522 \\
\hline
\end{tabular}

Table 2. Displays the global results of the satisfaction survey of the students.

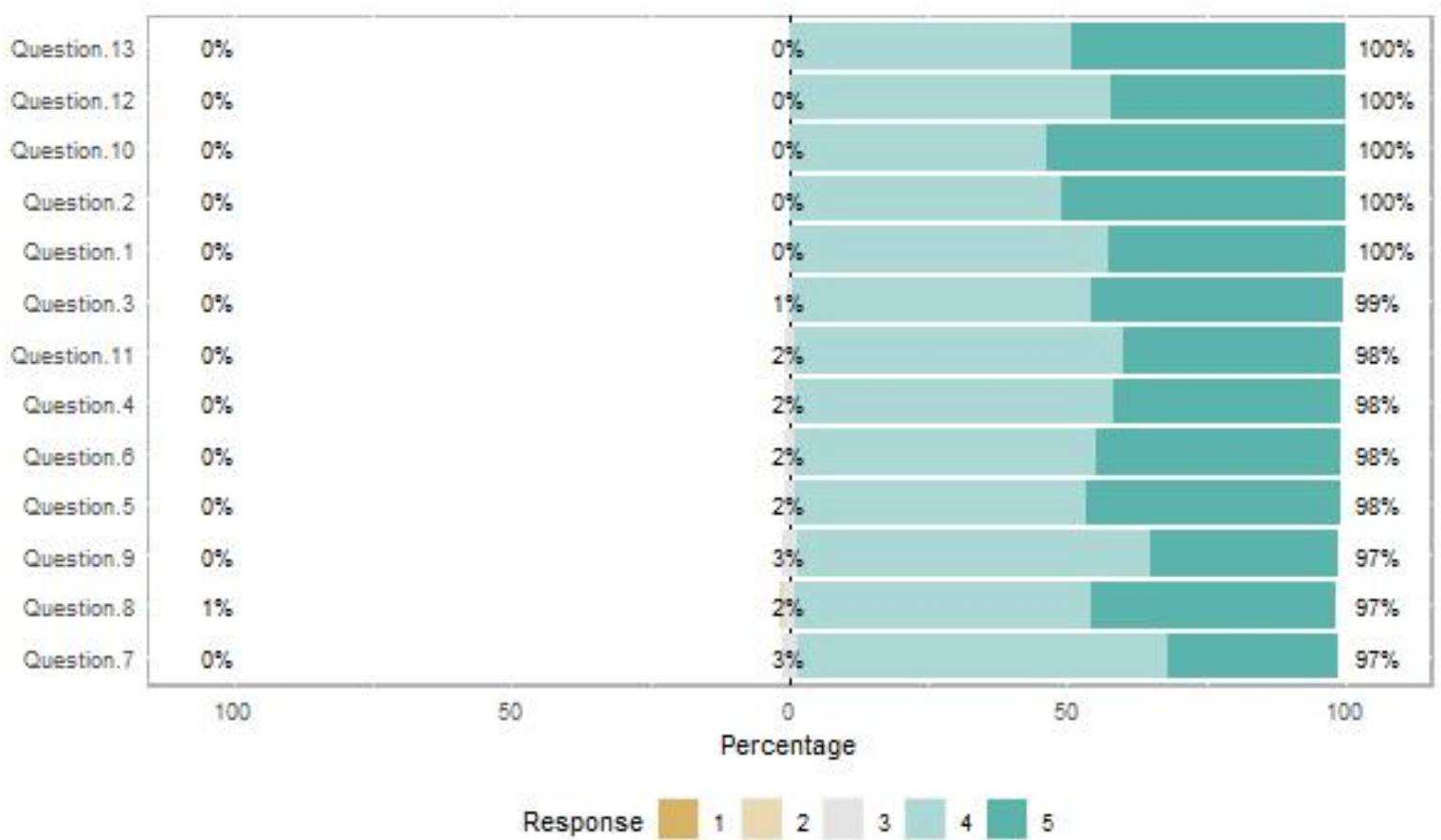

Figure 12. Displays the global results of the satisfaction survey, on the left the students' results and on the right the teacher's.

It seems through the global outcomes that all students and the teacher highly approve this methodology. Furthermore, as it is displayed in figure 1, the opinions stated by the teacher and the students are in the same line. As a result, the analysis is mainly focused on students' data since it allows us to provide information about standard deviation, the discussion between different opin- 
ions, etc.

Hereafter we will discuss the results obtained in the different categories:

\section{Teacher methodology:}

Table 3 displays the obtained results in the category of 'Teacher methodology'. All students seem to be highly satisfied with this type of methodology. The score obtained in questions 1 and 12 is outstanding because there is a $100 \%$ satisfaction. It is also observed that average scores of every question are alike and the variance, measured with the standard deviation is very low.

\begin{tabular}{|l|l|l|l|l|l|}
\hline Question & low & neutral & high & mean & sd \\
\hline Question 1 & 0 & 0 & 100 & 4.426 & 0.497 \\
\hline Question 12 & 0 & 0 & 100 & 4.423 & 0.496 \\
\hline Question 5 & 0 & 1.802 & 98.198 & 4.441 & 0.534 \\
\hline Question 6 & 0 & 1.802 & 98.198 & 4.423 & 0.531 \\
\hline Question 9 & 0 & 2.679 & 97.321 & 4.3125 & 0.520 \\
\hline Question 8 & 0.9001 & 1.802 & 97.297 & 4.405 & 0.578 \\
\hline
\end{tabular}

Table 3: Summary of 'Teacher methodology'

\section{Content acquisition:}

Table 4 displays the obtained results based on content acquisition. All students seem to be highly satisfied with this type of methodology. All students seem to be highly satisfied with acquiring content through ICT. The score obtained in questions 2 and 13 is outstanding because there is a $100 \%$ satisfaction. It is very positive to achieve this score in question 2 because it specifically refers to the impact gamification and multimedia have on content acquisition in music.

This remarkable result also appears in question 7 which is relevant because it displays how students expect to be taught this subject in the future. It is also observed that average scores of every question are alike and the variance, measured with the standard deviation is very low.

\begin{tabular}{|l|l|l|l|l|l|}
\hline Question & low & neutral & high & mean & sd \\
\hline Question 13 & 0 & 0 & 100 & 4.509 & 0.502 \\
\hline Question 2 & 0 & 0 & 100 & 4.491 & 0.502 \\
\hline Question 7 & 0 & 2.703 & 97.297 & 4.279 & 0.508 \\
\hline
\end{tabular}

Table 4. Summary of 'Content Acquisition'

\section{Teacher training:}

Table 5 displays the results obtained in teacher training. All students seem to be highly satisfied with acquiring content through ICT. All students seem to be highly satisfied with acquiring teacher training in the use of ICT in the classroom. The score obtained in question 3 is outstanding with more than $99 \%$ satisfaction. This question is relevant because it displays the importance students give to teach through ICT in all stages: Pre-school and Primary, therefore engaging students with these methodologies since they start learning and making them become familiar with it. It is also shown that the variance measure with the standard deviation is very low. 


\begin{tabular}{|l|l|l|l|l|l|}
\hline Question & low & neutral & high & mean & sd \\
\hline Question 3 & 0 & 0.893 & 99.107 & 4.446 & 0.517 \\
\hline
\end{tabular}

Table 5. Summary of 'Teacher Training'

\section{ICTs:}

Table 6 displays the results obtained in ICT. The score obtained in questions 4 is outstanding because there is a $100 \%$ satisfaction. The remarkable result obtained for this question is important because it represents the importance of ICT among the participants for all subjects, therefore being part of the methodology. Questions 10 and 11 also have remarkable results with more than $98 \%$ satisfaction among students. Compared to question 4 they are more specific because they refer to the use of gamification to foster motivation and cooperative work. The high scores on both general and specific questions show a global satisfaction with the use of ICT in the classroom. In question 12 there is a high satisfaction but it because more than $98 \%$ of students are in favour. It is also observed that average scores of every questions are alike and the variance, measured with the standard deviation is very low.

\begin{tabular}{|c|c|c|c|c|c|}
\hline Question & Iow & neutral & high & mean & sd \\
\hline Question 4 & 0 & 0 & 100 & 4.536 & 0.501 \\
\hline Question 10 & 0 & 1.786 & 98.214 & 4.375 & 0.522 \\
\hline Question 11 & 0 & 1.786 & 98.214 & 4.393 & 0.526 \\
\hline
\end{tabular}

Table 6. Summary of 'ICT'.

\section{Discussion}

These results display a high satisfaction among students to use gamification and ICT tools as a complement to traditional methodologies. These outcomes are in the same line and reinforce that CLIL and music are highly motivating for the students allowing them to be the main agents of the learning process, besides CLIL favours the integration of ICT.

It also shows that the use of these tools in the classroom relies directly on their satisfaction. Due to the positive results, it will also make learning through this innovative method more meaningful. We can also see through the figures that there is a low satisfaction among students to learn in a memorized way, which is a positive result because this is an innovative proposal where the students learn by doing. A high percentage of students agree that this methodology is really suitable to achieve the music contents through English and ICT. As a response to this innovative methodology the figures display a lack of preparation among Primary and Secondary teachers in ICT, furthermore students think it is a vital tool to integrate it in the classroom. To conclude, there is high dissatisfaction in the use of a textbook in a traditional way opposed to the proposed innovative methodology, where content is acquired through ICT and gamification.

The positive attitude of the teacher towards the proposed methodology helps and encourages his role as a mediator in the teaching / learning process. In addition, as the results are shown, the teacher considers these resources as a meaningful tool that could facilitate his work. In conclusion, this innovative methodology could be used to introduce CLIL and ICT, in addition to providing the necessary teacher training in this subject as well as in any subject. 


\section{References}

Adams, R., Nik Mohd Alwi, N. A., \& Newton, J. (2015). Task complexity effects on the complexity and accuracy of writing via text chat. Journal of Second Language Writing, 29, 64-81. https://doi.org/10.1016/ j.jslw.2015.06.002

Bartle, G. (1962). Music in the Language Classroom. Canadian Modern Language Review, 19(1), 11-14. https://doi.org/10.3138/cmlr.19.1.11

Baturay, M., Yıldııım, S., \& A. Daloğlu, A. (2009). Effects of Web-Based Spaced Repetition on Vocabulary Retention of Foreign Language Learners. Eurasian Journal of Educational Research (EJER), 34, 17-36.

Burke, B. (2014). Gamify: How Gamification Motivates People to do Extraordinary Things. Boston: Bibliomotion, INC.

Cabero Almenara, J., \& Barroso Osuna, J. (2016). Posibilidades educativas de la Realidad Aumentada. Journal of New Approaches in Educational Research, 6(1), 44-50. https://doi.org/10.7821/naer.2016.1.140

Coyle, D., Hood, P., \& Marsh, D. (2010). CLIL Content and Language Integrated Learning. Cambridge: Cambridge University Press.

Dalton-Puffer, C. (2007). Discourse in Content and Language Integrated Learning (CLIL) classrooms (Vol. 20). Amsterdam, The Netherlands: John Benjamins Publishing.

De Diezmas, E. N. M. (2018). Exploring CLIL contribution towards the acquisition of cross-curricular competences: A comparative study on digital competence development in CLIL. Revista de Linguistica y Lenguas Aplicadas, 13, 75-85. https://doi.org/10.4995/rlyla.2018.9023

Dourda, K., Bratitsis, T., Griva, E., \& Papadopoulou, P. (2013). Combining Game Based Learning with Content and Language Integrated Learning Approaches: A Case Study Utilizing QR Codes and Google Earth in a Geography-Based Game. The Electronic Journal of e-Learning, 12 (3), 243-258.

Espeso, P. (2017). 15 herramientas de gamificación para el aula que engancharán a tus alumnos. Educación 3.0. La revista para el aula del siglo XXI, 26 (45).

Falioni, J. W. (1993). Music as Means to Enhance Cultural Awareness and Literacy in the Foreign Language Classroom. Mid-Atlantic Journal of Foreign Language Pedagogy, 7, 97-108.

Fernandez Rodrigo, L. (2016). the Didactic and Methodological Use of Tablets in Classroms of Primary and Secondary Education in. Revista de Medios y Educación, 46, 9-25.

Fontecha, A. F. (2014). CALL syllabus integration through ICT-mediated tasks. Didáctica, Lengua Jy Literaura, $26,147-168$

Gaballo, V. (2010). Integrating content and language in specialized language teaching and learning with the help of ICT. ICT for Language Learning Conference Proceeedings., 29-24. http://www.pixel-online.net/ ICT4LL2010/common/download/Proceedings_pdf/CLIL02-Gaballo.pdf

Gallardo del Puerto, F., Gómez-Lacabex, E. \& García-Lecumberri, M. L. (2009). Testing the effectiveness of content and language integrated learning in foreign language contexts the assessment of English pronunciation. In Y. Ruiz de Zarobe \& R. M. Jiménez Catalán (Eds.), Content and Language Integrated Learning: Evidence from research in Europe, 63-80. Bristol, UK: Multilingual Matters.

Jolly, Y. S. (1975). The Use of Songs in Teaching Foreign Languages. The Modern Language Journal, 59(1-2), 11-14. https://doi.org/10.1111/j.1540-4781.1975.tb03618.x

Kaap, K.M. (2012). The Gamification of Learning and Instruction: Game- based Methods and Strategies for Training and Education. San Francisco: John Wiley \& Sons, Inc.

Marsh, D., Hau, K., \& Kong, S. (2000). Late immersion and language instruction in Hong Kong high schools: Achievement growth in language and non-language subjects. Harvard Educational Review, 70, 302346.

Mehisto, P., Frigols, M. J., \& Marsh, D. (2008). Uncovering CLIL. Oxford: Macmillan Education. 
Pantoja Vallejo, A., \& Montes, A. H. (2010). INTEGRACIÓN DE LAS TIC EN LA ASIGNATURA DE TECNOLOGÍA DE EDUCACIÓN SECUNDARIA INTEGRATION OF ICT INTO THE TECHNOLOGY SUBJECT IN SECONDARY EDUCATION (Vol. 37). https://idus.us.es/handle/11441/22627

Peregoy, S. F., \& Boyle, O. F. (2008). Reading, writing, and learning in ESL: A resource book for K-12 teachers (5th ed.). New York, NY: Addison-Wesley.

Rangel Baca, A. (2014). Competencias docentes digitales: propuesta de un perfil. Píxel-Bit, Revista de Medios y Educación, 46, 235-248. https://doi.org/10.12795/pixelbit.2015.i46.15

Richards, J. (1969). Songs in Language Learning. TESOL Quarterly, 3(2), 161. https://doi.org/ $10.2307 / 3586103$

Roca, F. (2004). Creatividad y comunicación musical desde las nuevas tecnologías. Creatividad y Comunicación Musical Desde Las Nuevas Tecnologías, 12(23), 31-36. https://doi.org/10.3916/25613

Rodríguez, R., Blázquez, M., López, B., Castro, M., San Cristobal, E., \& Martín, S. (2014). Educational games for improving the teaching-learning process of a CLIL subject: Physics and chemistry in secondary education", IEEE Frontiers in Education Conference (FIE) Proceedings, 1-8. https://doi.org/10.1109/ FIE.2014.7044064

Romero-Carmona, J.-B. (2004). New technologies and musical expression; other languages in education. Comunicar, 12(23), 25-30. https://doi.org/10.3916/c23-2004-05

Ruiz de Zarobe, Y., \& Lasagabaster, D. (2010). CLIL in Spain: Implementation, Results and teacher training. Newcastle, UK: Cambridge Scholars Publishing.

Saricoban, A., \& Metin, E. (2000). Songs, verse and games for teaching grammar. The Internet TESL Journal, 6 (10), 1-7. Retrieved from http:// iteslj.org/Techniques/Saricoban-Songs.html

Saz, O., Rodríguez, V., Lleida, E., Rodríguez, W. R., \& Vaquero, C. (2011). The use of multimodal tools for pronunciation training in second language learning of preadolescents. Language Teaching: Techniques, Developments and Effectiveness, January, 1-26.

Scott, D., \& Beadle, S. (2014). Improving the effectiveness of language learning: CLIL and computer assisted language learning. London: European Commission.

Teixes, F. (2015). Gamificación, motivar jugando. Barcelona. Editorial UOC.

Thain, L.A. (2010). Rhythm, Music and young Learners: A Winning Combination. JALT2009 Conference Proceeding, 407-416.

Toscano-Fuentes, C. M. (2010). Estudio empírico de la relación nivel de adquisición de una segunda lengua, la capacidad auditiva y la inteligencia existente entre el musical del alumnado. In Arias Montano. Repositorio Institucional de la Universidad de Huelva. http://hdl.handle.net/10272/4507

Vlachos, K. (2009). The Potential of Information Communication Technologies (ICT) in Content and Language Integrated Learning (CLIL): The Case of English as a Second/Foreign Language, in D. Marsh, P. Mehisto, D. Wolff, R. Aliaga, T. Asikainen, M.J. Frigols-Martin, S. Hughes \& G. Langé (eds.) CLIL Practice: Perspectives from the Field. University of Jyväskylä.

Willis, J. (2013). English through music Designing CLIL materials for young learners. Padres y Maestros, 349, 29-32. 